dr hab.inż Agnieszka Merkisz-Guranowska, prof.PP

Instytut Pojazdów Szynowych ,TABOR”,

Politechnika Poznańska

dr hab.inz. Marian Medwid, prof.IPS

dr Wlodzimierz Stawecki, prof.IPS

mgr inz. Jarosław Czerwiński

Instytut Pojazdów Szynowych ,TABOR”,

\title{
Innowacyjny system transportu naczep drogowych na wagonach towarowych w ruchu kombinowanym, kolejowo-drogowym
}

\begin{abstract}
$W$ artykule przedstawiono innowacyjnq koncepcje wagonu do transportu standardowych naczep drogowych $w$ ruchu kombinowanym. Opisano $w$ nim strukturę nośnq wagonu oraz sposób taczenia i ryglowania jego segmentów. Dokonano analizy różnych, wystęujacych na rynku rozwiazań ukladów zawieszenia i usprężynowania osi drogowych $w$ odniesieniu do przedstawionego wagonu. Przedstawiono poszczególne etapy załadunku naczepy drogowej na strukture nośna wagonu. Wytyczono dalsze kierunki badań naukowych nad rozwojem $i$ wdrożeniem innowacyjnych systemów transportowych $w$ ruchu kombinowanym.
\end{abstract}

\section{Wprowadzenie}

Znane środki transportu kolejowego naczep samochodowych umożliwiają przeładunek poziomy lub pionowy. Wagony przeznaczone do pionowego załadunku istotnie ograniczają możliwości transportu wyłącznie do specjalnie przystosowanych naczep. Wobec takiego ograniczenia oczywista jest przewaga środków przystosowanych do poziomego załadunku.

$\mathrm{Z}$ uwagi na sposób realizacji przeładunku naczep, można je zakwalifikować do trzech charakterystycznych grupach:

1. Skomplikowane konstrukcje wagonów o stosunkowo dużej masie własnej wyposażone w ruchome rampy najazdowe, umożliwiające samodzielny załadunek naczep z boku lub czoła wagonu.

2. Prostsze i lżejsze wagony których przeładunek możliwy jest jedynie na specjalnych rampach wyposażonych w mechanizmy napędowe przesuwu lub obrotu platform ładownych. Umożliwiają one przeładunek naczep z dowolnego wagonu w składzie pociagu.

3. Proste konstrukcje wagonów sprzęgniętych w składach wahadłowych w których następuje przeładunek całego składu pociągu na stacjach końcowych

Dobrym środkiem transportu uzupełniającym wyżej wymienione, byłby lekki wagon, prosty w konstrukcji i obsłudze, nie wymagający dodatkowych źródeł energii i napędów, umożliwiający samodzielny załadunek naczep na standardowym terminalu oraz transport $\mathrm{w}$ dowolnym składzie wagonów towarowych. W oparciu o zdobyte doświadczenie i opracowane konstrukcje dla transportu kombinowanego - wagonów, systemów modułowych i transportu bimodalnego, w IPS „TABOR" podjęto próbę opracowania takiego wagonu. Prace konstrukcyjne sfinansowano ze środków własnych. Jest przedmiotem zgłoszenia patentowego w Urzędzie Patentowym RP i jest zarejestrowane pod numerem P-408778.

\section{Prezentacja struktury nośnej wagonu}

Na rys. 1 przedstawiono dwuczłonowy wagon (moduł) 1 złożony z dwóch symetrycznych członów wagonu połączonych stale sprzęgiem krótkospiętym ․․ $\mathrm{Na}$ ramach nośnych członów wagonu umieszczono naczepy drogowe $\underline{\mathbf{3}}$

Na obu końcach modułu zabudowano konwencjonalne urządzenia pociagowo-zderzne $\underline{4}$. Prezentowana konstrukcja modułowa stanowi integralną jednostkę transportową czyli wagon, zdolną do tworzenia odpowiednich składów pociaggowych wyposażonych w pojazd trakcyjny.

Strukturę budowy jednego członu wagonu zilustrowano na rys. 2.

Każdy człon wagonu składa się z: 
- dwóch wózków tocznych $\underline{\mathbf{6}}$

- ramy nośnej zewnętrznej $\underline{7}$
- ramy nośnej wewnętrznej $\underline{\mathbf{8}}$

gdzie ramy nośne $\underline{\mathbf{7}}$ i $\underline{\mathbf{8}}$ są między sobą suwliwie połączone i odpowiednio zaryglowane.

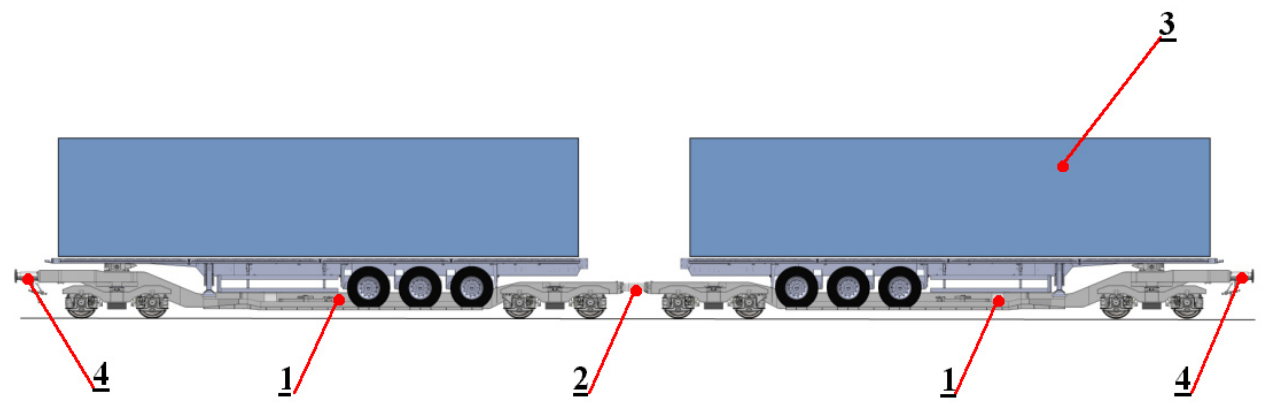

Rys.1 - Dwuczłonowy wagon transportowy

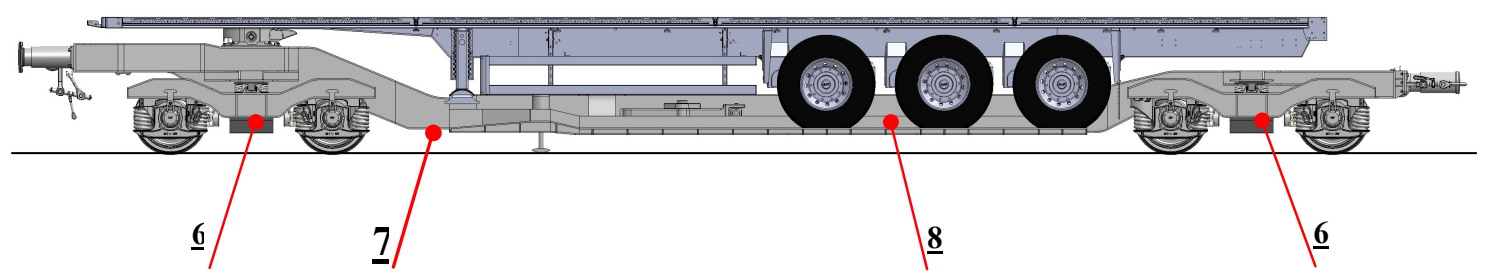

Rys.2 - Człon wagonu z naczepa

Człon wagonu bez naczepy pokazano na modelu rys. 2a, a rys. $2 \mathrm{~b}$ ilustruje człon wagonu z naczepa.

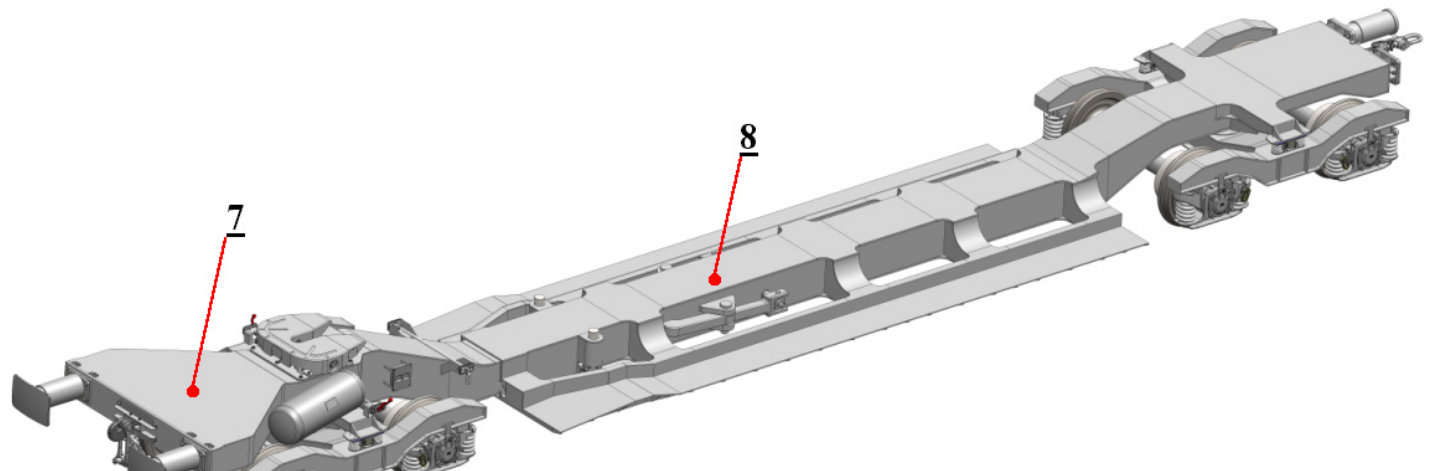

Rys. 2a - Człon wagonu przedstawiony na modelu przestrzennym

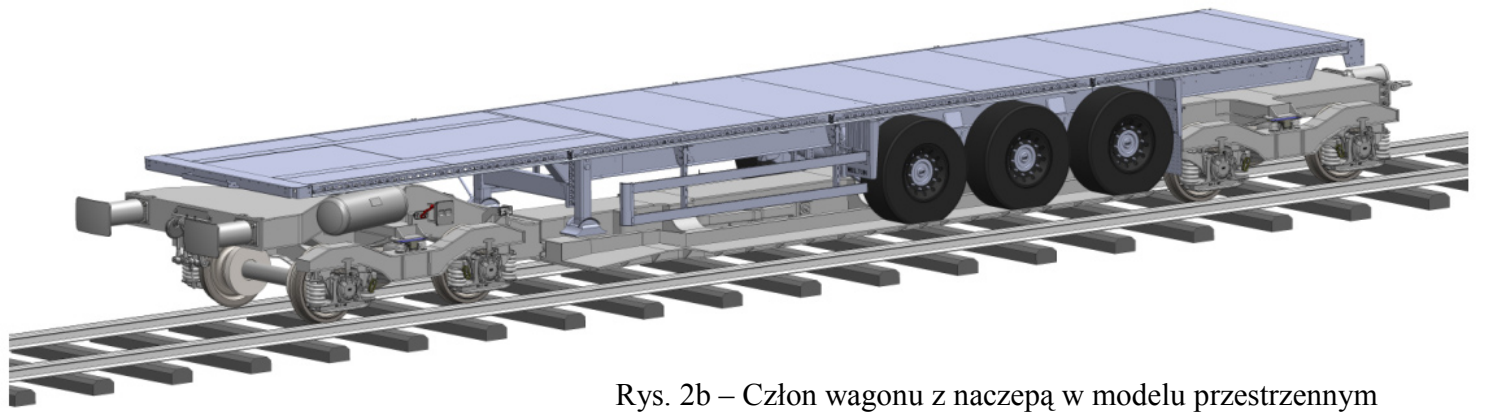

Człon wagonu w stanie rozłączonym zilustrowano na rys. 3, a części składowe: ramę zewnętrzną na wózku oraz ramę wewnętrzną na wózku pokazano na modelach przestrzennych rys. 4 i 5.

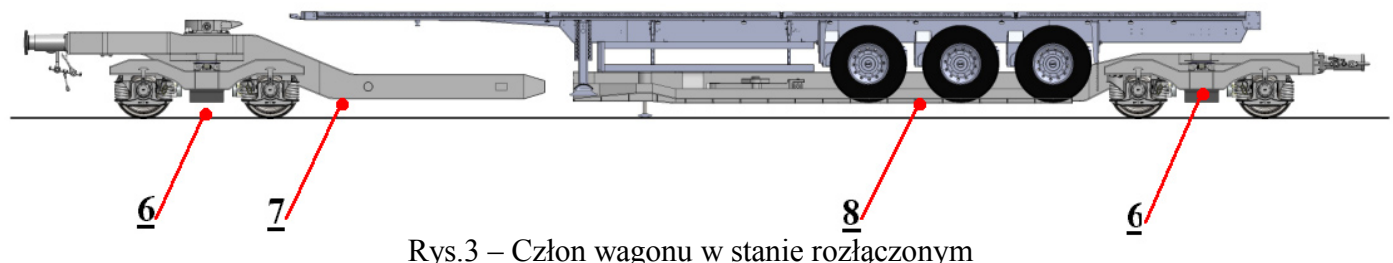




\subsection{Rama zewnętrzna na wózku.}

Rama 7 (rys. 3, 4) stanowi podstawową strukturę nośną segmentu zewnętrznego członu wagonu. Rama nośna jest spawaną konstrukcją skrzynkową złożoną z trzech głównych podzespołów:

- belki końcowej $\underline{\mathbf{8}}$

- belki nadwózkowej $\underline{9}$

- belki łącznikowej $\underline{\mathbf{1 0}}$.
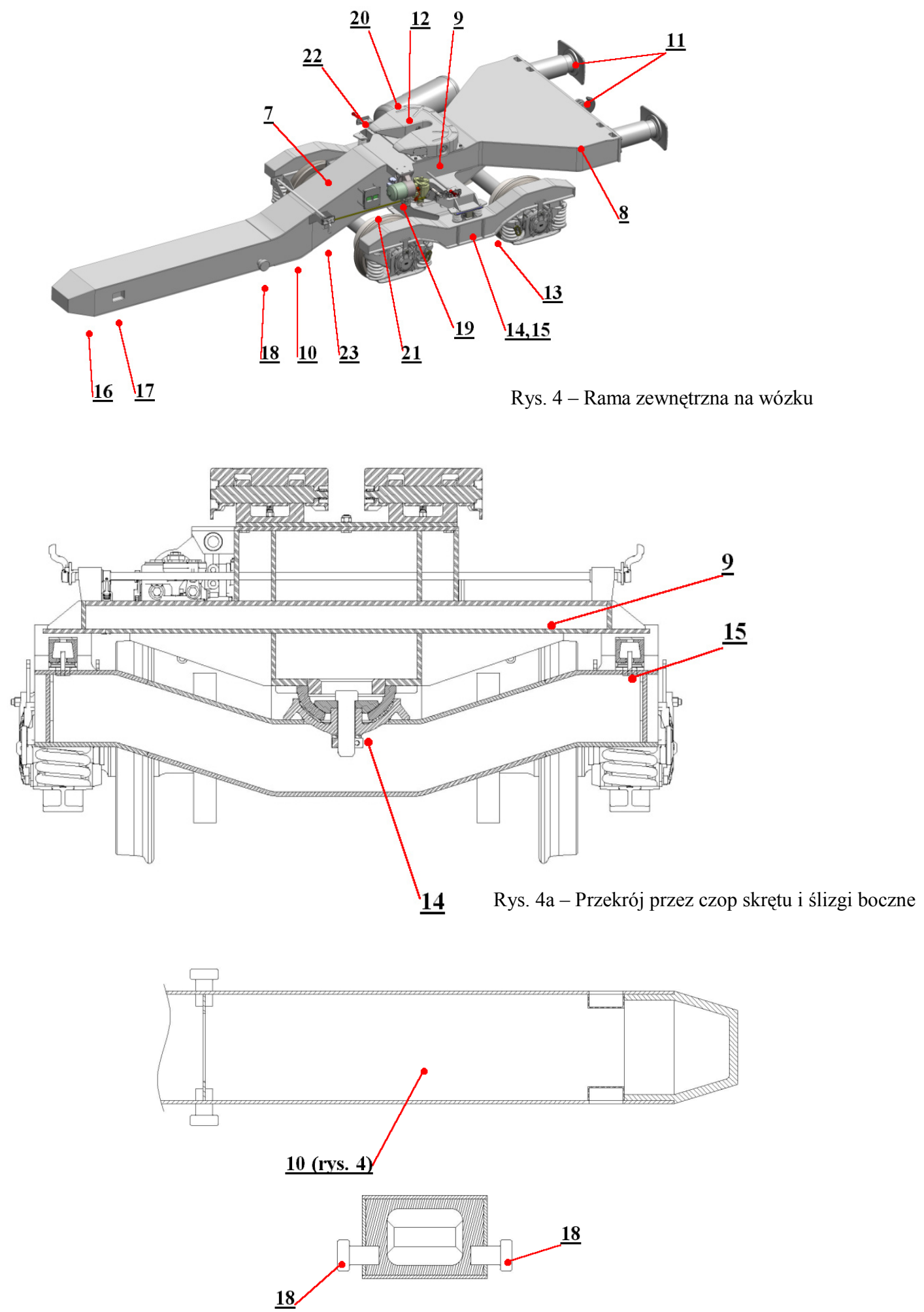

Rys. 4b - Przekroje belki łącznikowej poz. 10 (rys. 4) 
Na belce końcowej $\underline{\mathbf{8}}$ zabudowano urządzenia pociagowo-zderzne 1ㅡ. Na górnej płaszczyźnie belki nadwózkowej $\underline{\mathbf{9}}$ zabudowano siodło $\underline{\mathbf{1 2}}$, a w dolnej strefie belki umiejscowiono elementy składowe oparcia ramy nośnej $\underline{7}$ na ramie wózka $\underline{13}$ w postaci czopa skrętu $\underline{14}$ i ślizgów bocznych $\underline{15}$ (rys. $4 \mathrm{a}$ ). $\mathrm{Na}$ końcu belki łącznikowej $\underline{10}$ usytuowano czop naprowadzający $\underline{\mathbf{1 6}}$ (rys. 4b), a po obu stronach na pionowych ścian belki wykonano prostokątne otwory $\underline{\mathbf{1 7}}$. W dolnej części belki umieszczono czopy kołnierzowe $\underline{\mathbf{1 8}}$. Na ramie nośnej $\underline{7}$ zabudowano aparaty i urządzenia hamulcowe: zawór sterujący $\underline{\mathbf{1 9}}$,

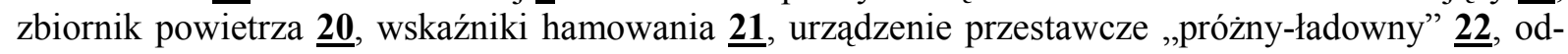
luźniacz hamulca $\underline{\mathbf{2 3}}$.

\subsection{Rama wewnętrzna na wózku.}

Rama nośna $\underline{\mathbf{8}}$ (rys. 3 i 5) jest spawaną konstrukcją skrzynkową złożoną z następujących połączonych ze sobą podzespołów:

- belki końcowej $\underline{\mathbf{2 4}}$

- belki nadwózkowej $\mathbf{2 5}$

- głównej belki nośnej $\underline{\mathbf{2 6}}$.

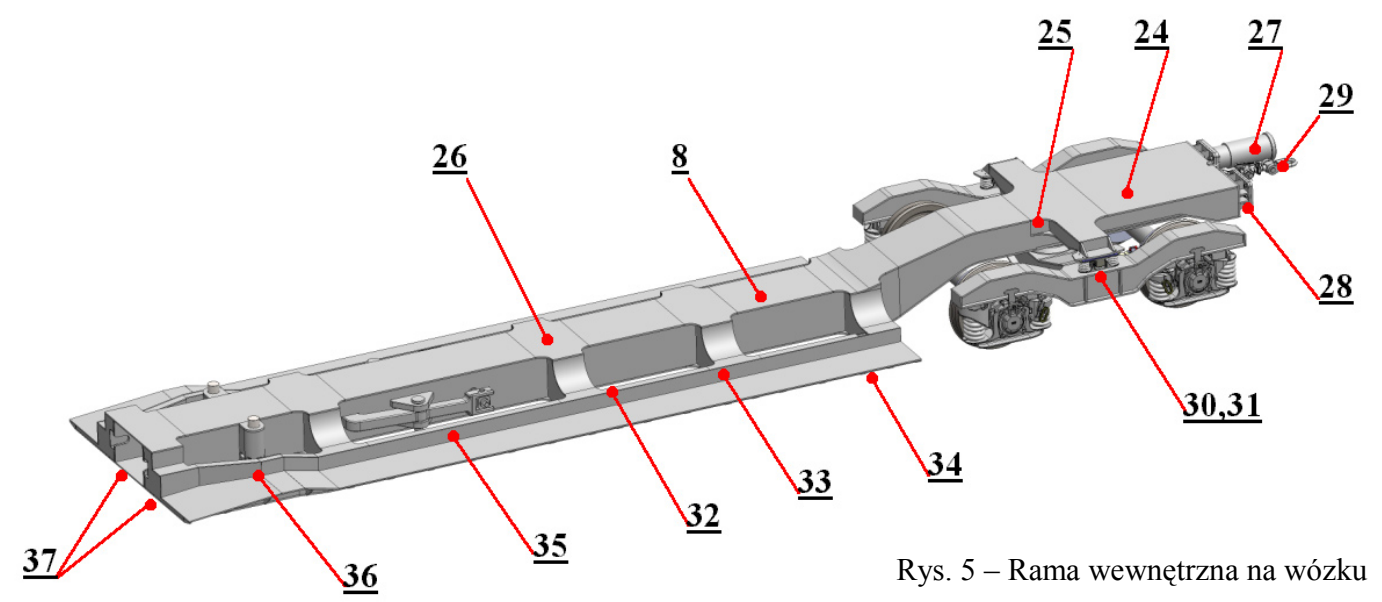

Na belce końcowej zabudowano urządzenia pociągowo-zderzne w postaci zderzaka $\underline{\mathbf{2 7}}$, płyty zderzakowej $\underline{\mathbf{2 8}}$ oraz urządzenia cięgłowego $\underline{\mathbf{2 9}}$.

Belka nadwózkowa ramy służy do zabudowy czopa skrętu $\underline{\mathbf{3 0}}$ oraz ślizgów bocznych $\underline{\mathbf{3 1}}$ które stanowią oparcie i mocowanie ramy nośnej na ramie wózka. Główna belka nośna $\underline{\mathbf{8}}$ jest złożona z belki centralnej $\underline{\mathbf{3 2}} \mathrm{o}$ przekroju prostokątnym do której po obu stronach belki za pomocą wsporników $\underline{\mathbf{3 3}}$ zamocowano półki nośne $\underline{\mathbf{3 4}}$. Ramę wyposażono w urządzenie ryglujące $\underline{\mathbf{3 5}}$ oraz podnośniki hydrauliczne $\underline{\mathbf{3 6}}$ zabudowane na pionowych ścianach bocznych belki centralnej. Na końcu belki centralnej po wewnętrznych stronach pionowych ścian belki wykonano odpowiednio ukształtowane wykroje $\underline{\mathbf{3 7}}$, a w dalszej części belki prostokątne otwory $\underline{\mathbf{3 8}}$ oraz czop oporowy $\underline{\mathbf{3 9}}$ zamykający przestrzeń wewnętrzną belki centralnej (rys. 5a) wykonany przez pionową płaszczyznę symetrii belki centralnej $\underline{\mathbf{3 2}}$.

\subsection{System ryglowania}

Urządzenie ryglujące $\underline{\mathbf{3 5}}$ bardziej szczegółowo przedstawiono na przekroju (rys. 5a,) które jest zabudowane

z następujących elementów składowych:

- $\quad$ wsporniki $\underline{40}$ mocowania dźwigni

- dźwignie ryglujące $\mathbf{4 1}$

- sworznie $\underline{42}$ mocowania dźwigni

- gwintowane kostki obrotowe $\underline{43}$

- pręt śrubowy $\underline{44}$ dwustronnie gwintowany.

a) Przekrój przez pionową płaszczyznę symetrii belki centralnej

b) Przekrój przez pionową poprzeczną płaszczyznę ramy nośnej z widokiem na urządzenie ryglujące 


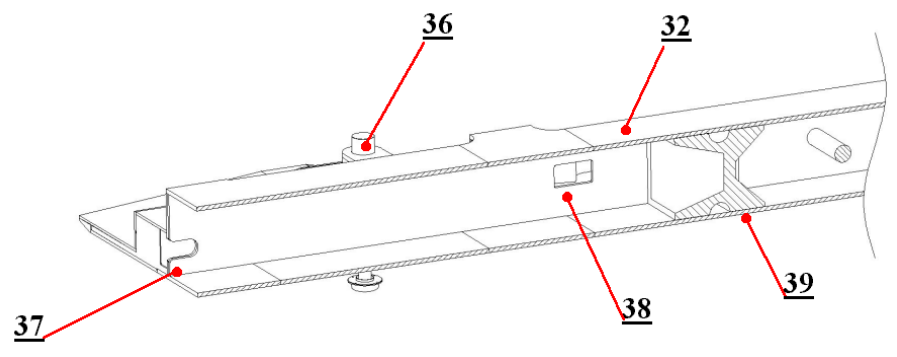

Rys.5a, b - Przekroje ramy nośnej

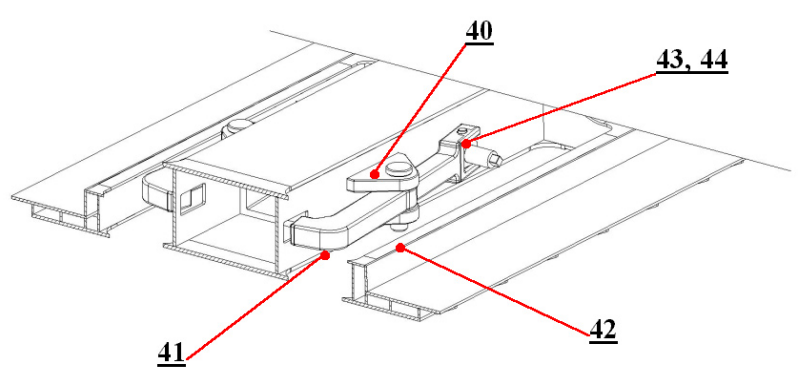

41

Zilustrowane na rys. 5b urządzenie ryglujące przedstawiono w stanie odryglowanym. Sposób połączenia i zaryglowania belki łącznikowej $\underline{\mathbf{1 0}}$ (rys. 4) z belką centralną $\underline{\mathbf{2 6}}$ (rys. 5) zaprezentowano na przekroju (rys. 6).

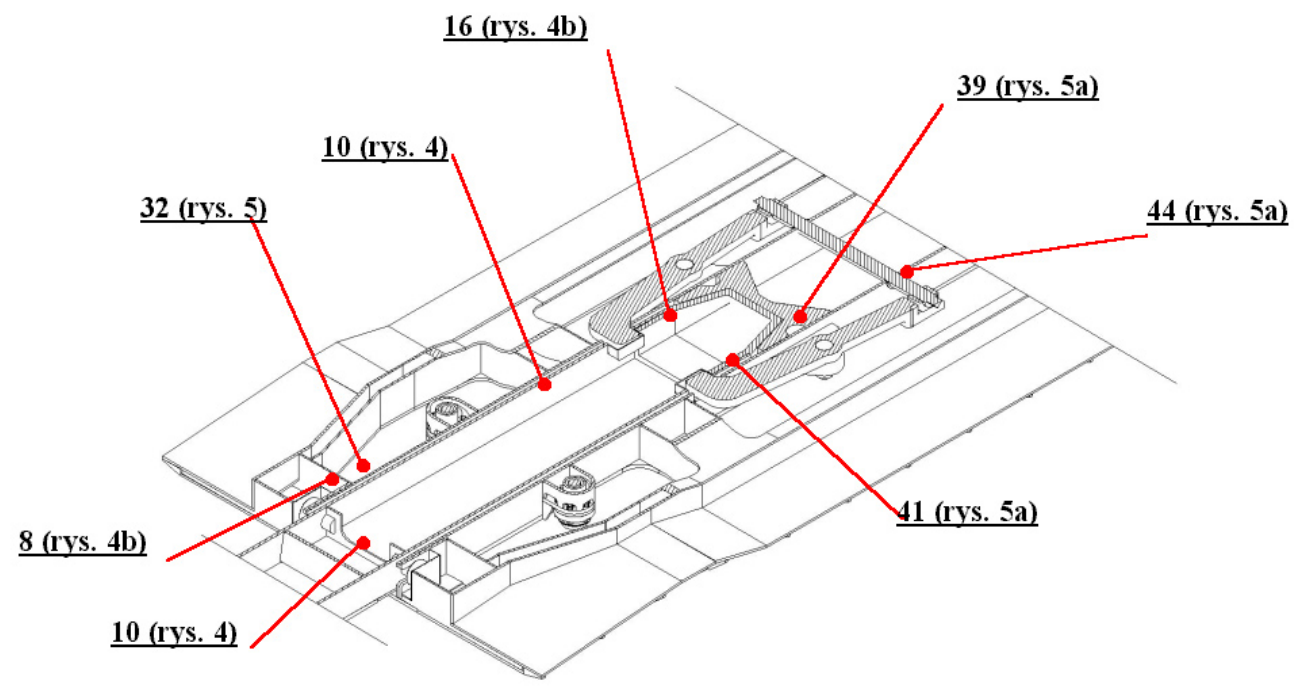

Rys.6 - Połączenie i ryglowanie belek ramy zewnętrznej i wewnętrznej jednego członu wagonu

W celu połączenia ramy zewnętrznej na wózku (rys. 4) z ramą wewnętrzną na wózku rys. 5 należy wprowadzić belkę łącznikową $\underline{\mathbf{1 0}}$ (rys. 4) w prostokątny otwór belki centralnej $\underline{\mathbf{3 2}}$ ramy wewnętrznej na wózku rys. 5 do oparcia czopa naprowadzającego $\underline{\mathbf{1 6}} \mathrm{w}$ gnieździe czopa oporowego $\underline{\mathbf{3 9}}$ (rys. 5a), oraz oparcia czopów kołnierzowych $\underline{\mathbf{1 8}}$ (rys. 4b) w wykrojach $\underline{\mathbf{3 7}}$ (rys. 5a) wykonanych w pionowych ścianach belki centralnej.

W tym położeniu belek ram nośnych należy wprowadzić końce dźwigni ryglujących w prostokątne otwory $\underline{\mathbf{1 7}}$ (rys. 4b) i $\underline{\mathbf{3 8}}$ (rys. 5a) wykonane w ścianach bocznych belki łącznikowej i belki centralnej, za pomocą pręta śrubowego $\underline{44}$ (rys. 5a) wykonując odpowiednią liczbę obrotów pręta śrubowego przy użyciu odpowiedniego klucza.

\section{Naczepa drogowa}

W prowadzonych analizach uwzględniono standardową naczepę skrzyniową produkowaną przez firmę Wielton w Wiedniu. Model przestrzenny, podwozia naczepy zaprezentowano na rys. 7.

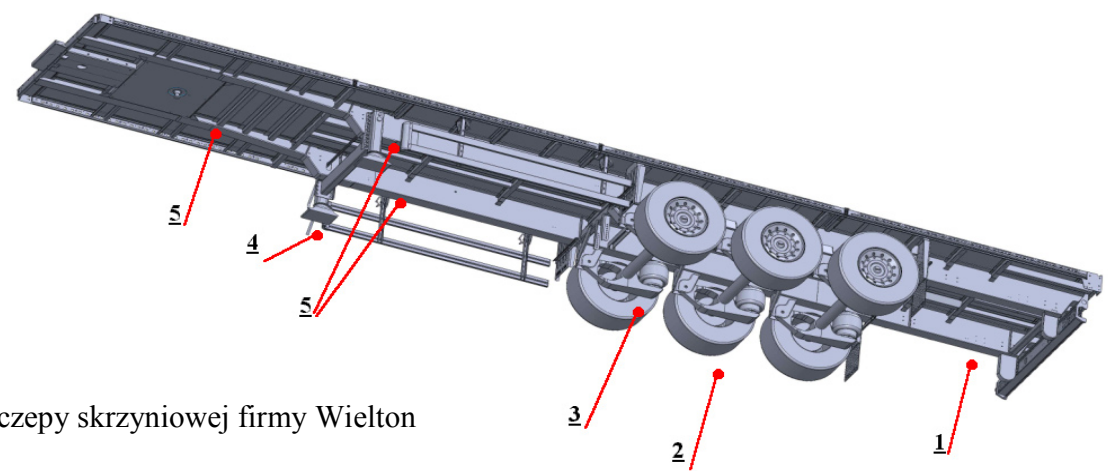

Rys. 7 - Standardowe podwozie naczepy skrzyniowej firmy Wielton 
Główne zespoły konstrukcyjne podwozia stanowią: rama nośna $\underline{\mathbf{1}}$, układ jezdny $\underline{\mathbf{2}}$, układ zawieszenia i usprężynowania $\underline{\mathbf{3}}$ oraz nogi podporowe $\underline{4}$.

W omawianej koncepcji wagonu do transportu naczep gdzie opony naczepy są usytuowane na zewnętrznych półkach ustrojów nośnych platformy jest wymagana odpowiednio duża przestrzeń poprzeczna pomiędzy wewnętrznymi powierzchniami opon i przestrzeń pionowa określona poziomem drogi i dolną powierzchnią osi drogowych.

W przestrzeni tej są umieszczone główne ustroje nośne platformy wagonu, które ze względów wytrzymałościowych muszą mieć odpowiednio duże gabaryty, które w tym przypadku zapewniają wystarczającą wytrzymałość konstrukcji.

Jedyne urządzenia zabudowane na osiach drogowych to prowadzenie usprężynowania osi zaprezentowane na rys. 8 zlokalizowane w pobliżu opon. Urządzenie jest złożone ze wspornika $\underline{1}$ zespolonego z ramą $\underline{\mathbf{2}}$ oraz wahacza $\underline{\mathbf{3}}$ zamocowanego obrotowo w wsporniku $\underline{\mathbf{1}}$. Na końcu wahacza $\underline{\mathbf{3}}$ na odpowiednio ukształtowanej półce zabudowano miech nośny $\underline{\mathbf{4}}$, który oparto i zamocowano dolnym kołnierzem do półki wahacza $\underline{\mathbf{3}}$, a górny kołnierz miecha zamocowano do wspornika ramy $\underline{\mathbf{5}}$.
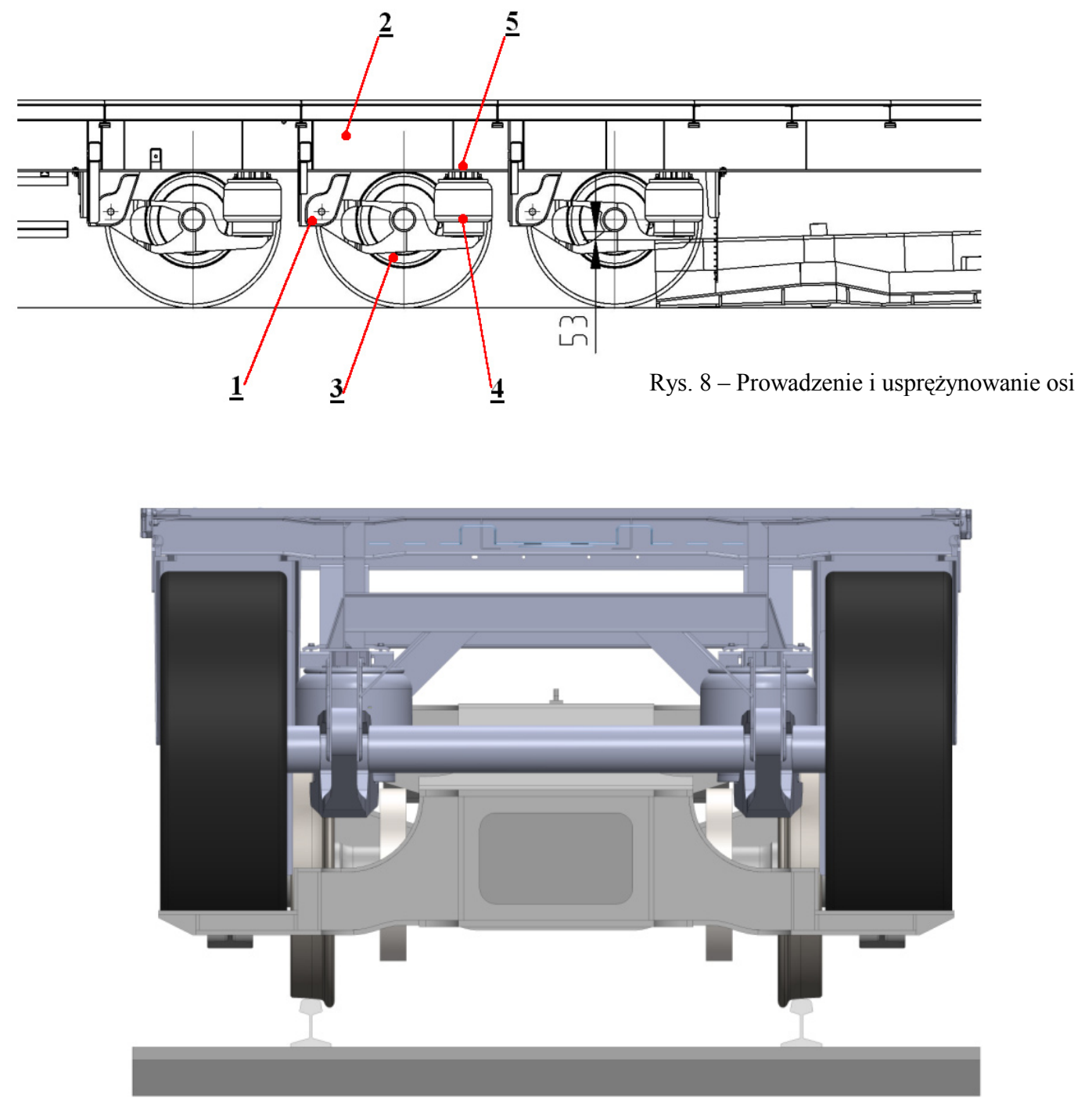

Rys. 9 - Przekrój poprzeczny przez wagon z naczepa

Na poprzecznym przekroju rys. 9 poprowadzonym przez podwozie naczepy i ustrój nośny wagonu pokazano wykorzystanie wolnej przestrzeni pomiędzy oponami i osią drogową naczepy. Kształt przekroju wagonu wynika z konieczności zagwarantowania odpowiednio dużej wolnej przestrzeni dla układu zawieszenia naczepy. Do analizy wybrano rodzaj zawieszenia zastosowanego w naczepie Wielton.

W tabeli 1 zaprezentowano inne typy zawieszeń stosowanych przez producentów naczep, które również mieszczą się w przestrzeni wyznaczonej dla zawieszenia osi drogowych. 


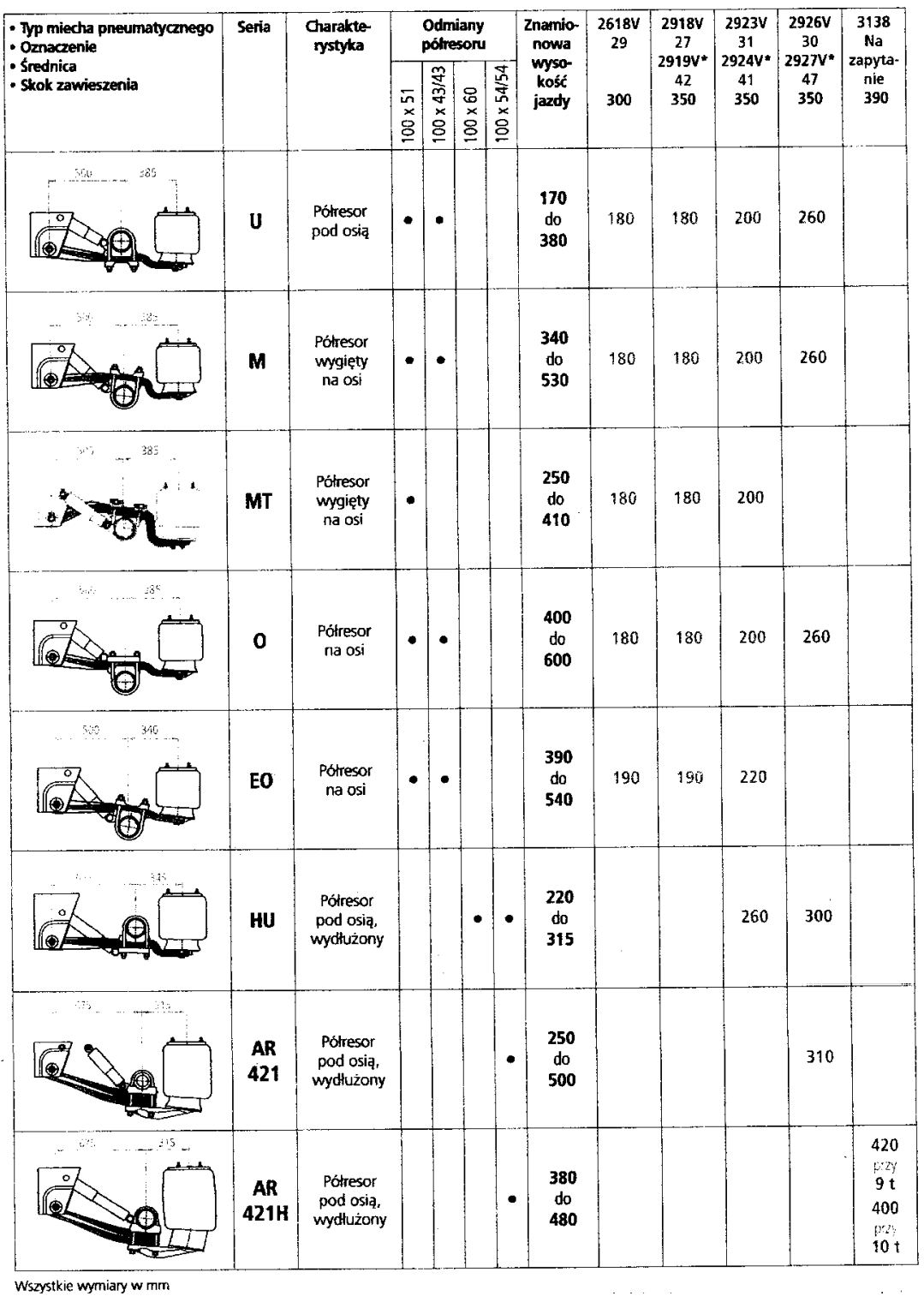

\section{Załadunek naczep na wagon.}

Załadunek naczep na wagon jest realizowany na terminalu z odcinkiem toru prostego ułożonego na poziomie terminalu. Do przeładunku naczep wykorzystuje się metodą poziomego przeładunku bez korzystania z dźwigowych urządzeń przeładunkowych.

Poszczególne etapy załadunku naczepy na wagon zilustrowano na rys. 7.

Do załadunku naczep na wagonie należy przygotować dwa segmenty wewnętrzne członu wagonu połączone sprzęgiem krótkospiętym, tak aby końce ram nośnych opartych na siłownikach hydraulicznych były opuszczone do poziomu terminala. Wózki zahamować hamulcem ręcznym, a pod koła osi zestawów podłożyć płozy hamujące (rys. 7a).

Za pomocą ciagnika siodłowego wprowadzić tyłem naczepę na półki ramy nośnej, tak aby opony tylnej osi jezdnej zostały oparte na ogranicznikach półek (rys. 7b).

Opuścić podpory naczepy do oparcia na półkach ramy nośnej, opróżnić miechy nośne z powietrza, wyjechać ciagnikiem siodłowym spod przodu naczepy (rys. 7c).

Za pomocą hydraulicznej pompy ręcznej lub agregatu pompowego podłączonej do siłowników hydraulicznych unieść ramę nośną do poziomu równoległego do podłoża terminala. Przetoczyć wózek z ramą zewnętrzną w kierunku ramy nośnej segmentu wewnętrznego, aby czop naprowadzający belki łącznikowej trafił w otwór belki centralnej ramy segmentu wewnętrznego (rys. 7d). Przepchać wózek z ramą zewnętrzną do oparcia czopa naprowadzającego o czop oporowy zabudowany w belce centralnej oraz oparcia siodła naczepy na siodle ramy nośnej zewnętrznej. 
a)

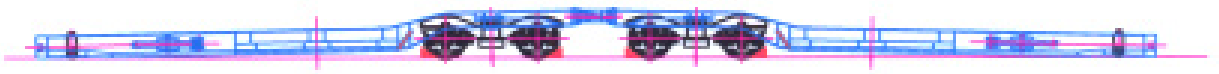

b)

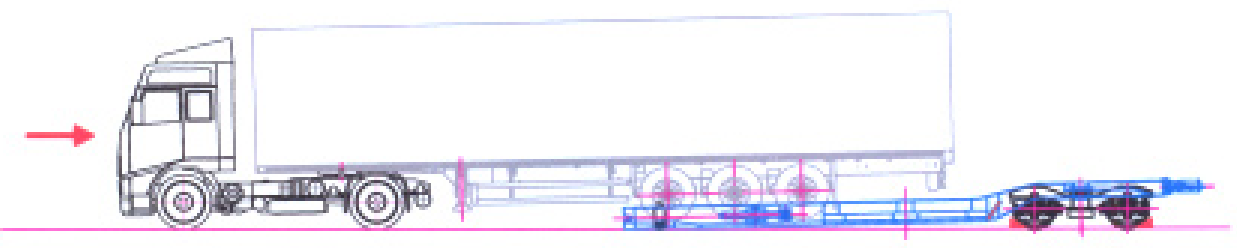

c)

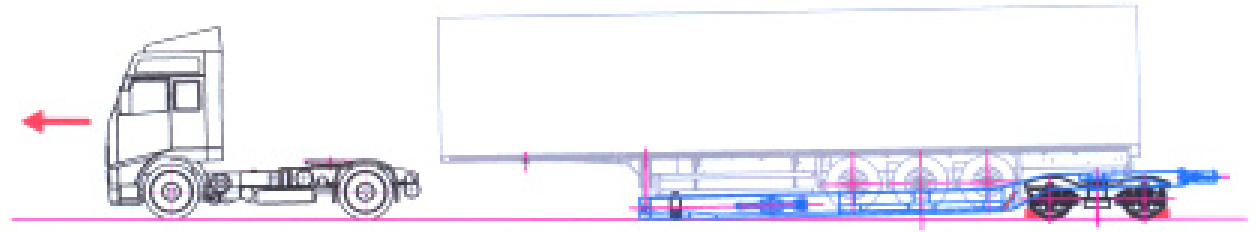

d)

e)

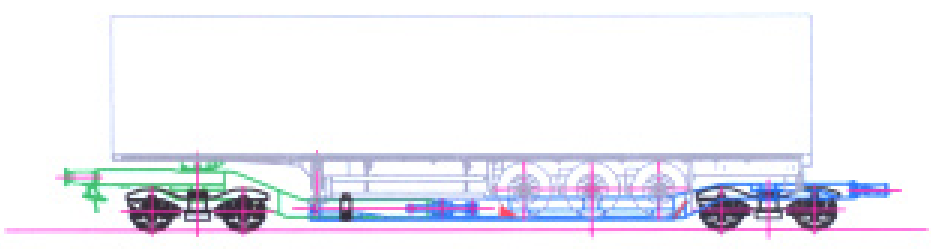

f)

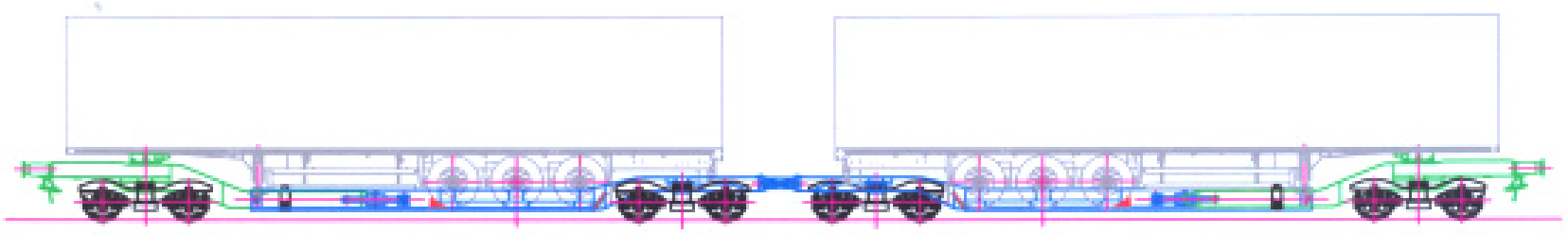

Rys.7 - Etapy procesu załadunku naczepy

Za pomocą odpowiedniego klucza zaryglować belką łącznikową w belce centralnej, łącząc w ten sposób człon wagonu. Unieść nogę podporową naczepy oraz podpory hydrauliczne zabezpieczyć odpowiednim klinem opony przedniej osi naczepy, odhamować wózek ramy wewnętrznej i wyjąć płozy spod kół wózka (rys. 7e).

W podobnej kolejności załadować naczepę na drugim członie wagonu (rys. 7f).

Prezentowany system transportowy pozwala na jednoczesny załadunek na wagon dwóch naczep co o połowę skraca czas formowania składu. Niezbędna do załadunku naczep hydrauliczna pompa może być na wyposażeniu terminala lub wożona na wagonie, umieszczona na belce końcowej ramy nośnej wewnętrznej. 


\section{Podsumowanie}

Zaprezentowana $\mathrm{w}$ artykule koncepcja wagonu dwuczłonowego jest realną konstrukcją zweryfikowana przeprowadzonymi wstępnymi badaniami symulacyjnymi wytrzymałości ustrojów nośnych wagonu oraz w zakresie wymagań dotyczących bezpieczeństwa i dynamiki ruchu pociagu.

Rozwiązanie konstrukcyjne wagonu zostało zgłoszone do ochrony w Urzędzie Patentowym RP i jest zarejestrowane pod numerem P-408778.

Polska należy do grupy największych przewoźników drogowych w Europie. Aby zmniejszyć negatywne skutki oddziaływania transportu drogowego na bezpieczeństwo ruchu na drogach oraz na środowisko naturalne należy przekierować część naczep drogowych na środki transportu kolejowego. Prowadzone w ostatnich latach inwestycje w polskich portach (kontenerowy terminal przeładunkowy w Gdańsku oraz gazoport w Świnoujściu) prowadzą do kumulacji dużej masy towarowej skoncentrowanej na bardzo małym obszarze kraju. Sprawne dostarczenie towarów do odbiorów krajowych i zagranicznych stanowi duże wyzwanie logistyczne. Winno też inspirować spedytorów do wdrażania innowacyjnych technologii transportowych. Jedną z nich może być technika transportu bimodalnego z wykorzystaniem cystern bimodalnych do przewozu gazu skroplonego z Gazoportu Świnoujście do krajowych odbiorców gazu.

System bimodalny można z powodzeniem zastosować do przewozu kontenerów wykorzystując uniwersalność systemu. W logistycznym łańcuchu transportowym należy przewidzieć zarówno pionowy przeładunek kontenerów na terminalach $\mathrm{z}$ urządzeniami dźwigowymi oraz przeładunek poziomy charakterystyczny dla transportu bimodalnego na terminalach bez przeładunkowych urządzeń dźwigowych.

Prezentowana $\mathrm{w}$ artykule koncepcja wagonu dwuczłonowego jest kolejną innowacyjną propozycją IPS „TABOR” do wykorzystania w ruchu kombinowanym kolejowo-drogowym.

\section{Literatura}

[1] Madej J., Medwid M. Cichy R, Jakuszko W., Nowaczyk T.: Modułowy system transportu naczep środkowych na wózkach kolejowych w ruchu kombinowanym kolejowo-drogowym. Pojazdy Szynowe 2/2012.

[2] Merkisz-Guranowska A., Czerwiński J.: Stan rozwoju transportu intermodalnego w przewozach kolejowych kombinowanych w Polsce. XXI Konferencja Naukowa Pojazdy Szynowe. Wrocław-Wojanów, maj 2014.

[3] Tomaszewski F., Medwid M., Nowaczyk T., Czerwiński J.: Cechy charakterystyczne modułowego systemu transportu naczep drogowych $w$ odniesieniu do znanych systemów transportowych $w$ ruchu intermodalnym kolejowo-drogowym. XXI Konferencja Naukowa Pojazdy Szynowe. Wrocław-Wojanów, maj 2014.

[4] Madej J., Medwid M., Cichy R., Nowaczyk T.: Wybrane aspekty procesu tworzenia modelu modułowego systemu naczep drogowych w ruchu kombinowanym. XXI Konferencja Naukowa Pojazdy Szynowe. Wrocław-Wojanów, maj 2014.

[5] Madej J., Medwid M., Stawecki W.: Bezpieczny sprzęg międzynaczepowy dla modułu kolejowego uformowaniu naczep drogowych $w$ kombinowanym ruchu kolejowo-drogowym. XXI Konferencja Naukowa Pojazdy Szynowe. Wrocław-Wojanów, maj 2014. 